Article

\title{
Individual and Social Preferences in Participatory Multi-Criteria Evaluation
}

\author{
Itziar Barinaga-Rementeria ${ }^{1, *}$, Artitzar Erauskin-Tolosa ${ }^{2}{ }^{\mathbb{D}}$, Pedro José Lozano ${ }^{3}$ and \\ Itxaro Latasa ${ }^{4}$ \\ 1 Department of Accounting and Finance, University of the Basque Country (UPV/EHU), \\ 01006 Vitoria-Gasteiz, Spain \\ 2 Department of Applied Economics I, University of the Basque Country (UPV/EHU), 20018 Donostia, Spain; \\ artitzar.erauskin@ehu.eus \\ 3 Department of Geography, Prehistory and Archeology, University of the Basque Country (UPV/EHU), \\ 01006 Vitoria-Gasteiz, Spain; pedrojose.lozano@ehu.eus \\ 4 Department of Architecture, University of the Basque Country (UPV/EHU), 20018 Donostia, Spain; \\ itxaro.latasa@ehu.eus \\ * Correspondence: itziar.barinagarementeria@ehu.eus; Tel.: +34-945-01-4372
}

Received: 15 September 2019; Accepted: 15 October 2019; Published: 17 October 2019

\begin{abstract}
Decisions on environmental issues are complex and multidimensional as they represent multiple interests and values. Nevertheless, the ability of participatory multi-criteria methodologies to deal with this kind of problem is widely acknowledged. Traditionally, multi-criteria methods have focused more on technical issues than on the representation of participants' preferences. In participatory processes there are questions such as who establishes the mechanisms of participation, in what terms these processes are developed and who is going to participate, which are determining factors that have not been sufficiently studied in multi-criteria analysis. This paper, in order to shed light on this gap, aims to compare the creation of social preferences under two different participatory approaches. For this purpose, two different participatory approaches are compared. On the one hand, applying the social multi-criteria evaluation (SMCE) method, a deliberative process is developed following the principles of deliberative democracy. On the other hand, an aggregation process of individual preferences has been developed based on information collected through surveys. Both approaches have advantages as well as constraints. Our main finding is that the information obtained through the different participatory methods is different and complementary. Therefore, we can state that both participatory methods can be enriching assessment processes.
\end{abstract}

Keywords: preference formation; participatory multi-criteria evaluation; environmental decision-making

\section{Introduction}

The Deliberative Approach in Decision-Making

Decisions on environmental issues are complex and multidimensional. Socio-ecological systems often present immeasurable valuations, a high degree of uncertainty, and divergent points of view on problems [1-4]. In addition, these decisions affect heterogeneous groups of stakeholders and reflect a broad range of interests, which are often in conflict [5]. The need to integrate economic, ecological, social, and cultural aspects simultaneously increases the complexity of the decisions. However, most analyses of environmental issues have mainly focused on a single dimension and value, usually approaching from disciplinary perspectives: monetary (cost-benefit analyses), biophysical, or sociocultural analyses [6]. Traditional methods of assessment based on a single criterion may be complementary [7], but are not sufficient to describe and analyze the complexity of these issues [8,9], 
nor to respond to the social requirements of sustainability [10]. So, new methods of analysis have emerged that consider social participation as part of decision-making processes [11-13].

An integrative combination of analytical and participatory approaches allows decision-makers to consider different values and interests [14]. In order to achieve sustainable decisions, it is important to consider all points of view on the problem, i.e., the representation of civil society, the inclusion of technical knowledge, and the participation of institutions and interest groups are key elements in the management of natural resources [15-17].

Among the new participatory methods, multi-criteria methods have emerged as adequate supports for decision-making on environmental management problems $[2,3,18]$. The multi-criteria methodology considers multiple dimensions of environmental issues, works with quantitative and qualitative information and considers the uncertainty in the future [19]. Therefore, the multi-criteria methodology offers appropriate tools for working with the complexity of environmental decisions, and is particularly suitable for structuring environmental problems [20]. However, its rather technical approach has focused more on issues such as the aggregation of assessments of different criteria than on the legitimacy of the interests represented in participatory processes $[14,21,22]$. Social participation in decisions on natural resource management still raises basic questions, such as the degree of linkage in the agreements made, the representation and inclusion of different interests and points of view, and the different procedures of social participation [23-25].

In addition, numerous research papers, both theoretical [26] and case studies [27-32], show an interest in the combination of different methods of participation and the contrast between the results obtained, as developed in this work. The application of two different methods of social participation makes it possible to observe the similarities and differences in the results and to verify the effect that the participatory method used has on them.

The aim of this study is to shed light on these gaps in participatory multi-criteria methods by exploring the creation of social preferences through different participatory methods. To this end, a case study has been carried out on the possible uses of rural land in a municipality on the Cantabrian side of the Iberian Peninsula, Mutriku, in Gipuzkoa (Spain), coinciding with the preparation by the local administration of a general urban development plan (GUDP). For this evaluation process, a deliberative participatory process has been developed following the multi-criteria social evaluation method $[3,4]$. In addition, to compare the results, a multivariate analysis has been applied to the information obtained through a survey of a representative sample of the population of the aforementioned municipality.

\section{Participation in Multi-Criteria Evaluation}

Initially, multi-criteria evaluation was characterized by the principles of multi-criteria decision-making (MCDM) without social participation or with minimal participation [33]. Progressively multi-criteria decision analysis (MCDA) identified the participation of social actors as a fundamental element [20,34-37]. These methodologies have been developed as tools to assist with natural resource management decisions within the framework of sustainability principles [38-42].

\subsection{Selection of Participants: Representation and Inclusion of Different Visions}

Among the multi-criteria methods with social participation, different rationalities can be distinguished in the pursuit of social participation. Fiorino [43], in his pioneering work on social participation, describes substantive, normative, and instrumental arguments that justify participatory processes compared to technocratic approaches: (i) according to substantive arguments, the quality of processes is enhanced by considering problems, issues, or solutions of actors that may not be taken into consideration when decisions are based solely on expert knowledge [44]; (ii) normative arguments defend the notion that democratic principles require the incorporation of all visions in decision-making processes; and (iii) instrumental arguments show that social participation gives legitimacy to decision-making processes, and that the adopted agreements are more likely to be accepted and therefore more efficient $[45,46]$. 
Socio-ecological systems are complex and there are different points of view and value systems concerning them [47]. The inclusion and representation of all points of view is an important issue in participatory processes $[5,7,22]$ as far as it ensures the quality and legitimacy of the proposed agreements or solutions. However, it is difficult to achieve in operational terms [48]. Additionally, decisions on natural resource management have consequences that are far-reaching both in space and time. So, determining the area and population on which they will have an effect is not a straightforward task. Questions such as who establishes the participatory methods, in what terms these processes are developed, to what extent the agreements will be binding, and the role of the citizenry in participatory processes are raised [15,49-51]. The selection of participants is one of the key issues in the problem of representativeness [52,53], and the authors of [14] point out the importance of including a wide range of participants to obtain scientific, technical, and local knowledge. This implies covering a broad spectrum of participants [52] so that the risks and problems of the place are represented and researchers develop dynamics that facilitate the participation of all the actors in a noncoercive way through different participation procedures [54].

\subsection{Individual Preferences and Group Deliberation}

The definition of social preferences in environmental management decisions is another issue still under discussion. The individual perception of well-being is a subjective matter. In addition, as Arrow [55] points out, it is not easy to establish norms or precise rules that allow for the aggregation of individual preferences in a way that satisfies the criteria necessary to value social welfare. Participatory methods are based on the preferences of individuals. However, the aggregation of these individual preferences and the development of social preferences are issues under discussion.

Two main general approaches have been developed to explain the creation of social preferences from individual preferences. On the one hand, methods based on the neoclassical theory indicate that individuals seek to maximize their own utility [22] and therefore the satisfaction of individual preferences will satisfy social preferences [56]. From this paradigm, it is possible to calculate the gradients of preferences, needs, and expectations of social groups by aggregating individual preferences arithmetically. So, optimal representation is guaranteed through democratic processes by consulting a broad sector of society and carrying out a statistical extrapolation of the information gathered. However, this approach may present deficiencies when aggregating individual information [57]. As Kenter [58] points out, the choice of aggregation method involves a certain degree of subjectivity.

On the other hand, institutionalist or deliberative approaches are mainly based on: (i) the political theories of communicative action [59], which argues that preferences and values are socially constructed, and (ii) the principles of deliberative democracy, which considers deliberative processes as the basis of democratic legitimacy $[25,60]$. These approaches rely on communication to develop the norms and institutions needed in the search for solutions [22,31], so group deliberation, communication processes, and mutual learning are the way to define social preferences, instead of reaching them through mere mathematical calculations [12,61-63].

Deliberative processes entail a period of reflection and debate. Structured confrontation of interests and values allows for reflection and the emergence of new social values. Through participation processes, the actors, in addition to learning from the rest of the participants, reflect on their own values by developing social learning processes, and if enough involvement in the deliberative process is achieved, they reflect as a social unit $[12,25,28]$. Proof of this is the change in individual preferences perceived when the same actors have participated in different group deliberation processes [64]. So, deliberation groups can offer the opportunity to find compromises and create social preferences, fulfilling the social principles of sustainability and social equity [58] and incorporating the social vision into political decisions [60]. Thus, a deliberative approach could be a key element in overcoming the complexity, uncertainty, and risk of conflict inherent in natural resource management [65].

However, deliberative processes have certain limitations. On the one hand, deliberative approaches focus on qualified stakeholders, acting as representatives of groups with a common interest [66]. 
In deliberative processes the groups are small, and the stakeholders must represent all interests. This is why problems of representativeness arise. The selection of participants is one of the key issues related to those problems of representativeness [52,53].

On the other hand, the authors of [31] point out that there is a risk of working with biased information or only with certain points of view. Different power dynamics among stakeholders may be considerable. Authors such as Cornwall [67] and Kolinjivadi et al. [68] point out that there are processes by which a social group exerts influence over the rest by imposing its criteria, as well as asymmetry in information among participants, or even the self-exclusion of certain social sectors due to their weakness or the fact that they cannot participate.

In the following section we use a case study to present a comparative analysis of deliberative participatory approaches and the aggregation of individual preferences with the aim of testing in a real case the contributions and limitations of both participatory approaches.

\section{Case Study}

Rural areas in Europe's industrialized regions have undergone major changes in recent decades due to changing agricultural and forestry patterns and urban pressure. Rural areas are no longer valued solely for their role as agricultural producers, but offer different alternatives for use, often in conflict with each other. Nowadays, apart from their agricultural value, rural spaces are recognized for offering fundamental environmental, social, and cultural services [69-72]. This transformation of nonurban land use requires management policies adapted to their new demands and perspectives.

Our case study focuses on the sustainable development of the Mutriku rural area (Figure 1), located in the Basque Country of southern Europe, coinciding with the preparation of the Municipal Land-Use Plan (MLUP). This municipality occupies an area of approximately 2800 hectares. Due to its particular location, with a very mountainous orography and narrow valleys, and not being on the axis of main roads, the degree of industrial development of this municipality has been lower than the rest of the municipalities in the region. Thus, the area has basically maintained the traditional landscape of the mid-mountain rural areas of the Basque Country. The forest occupies a large part of the soil of Mutriku, i.e., $75.76 \%$ of the surface (Forest Inventory, 2010), with a notable increase in non-native species in recent decades. The massifs of Izarraitz, Andutz, and Arno stand out, the latter being a Special Conservation Area (SAC) due to the great value of the Atlantic holm oak that abounds there.

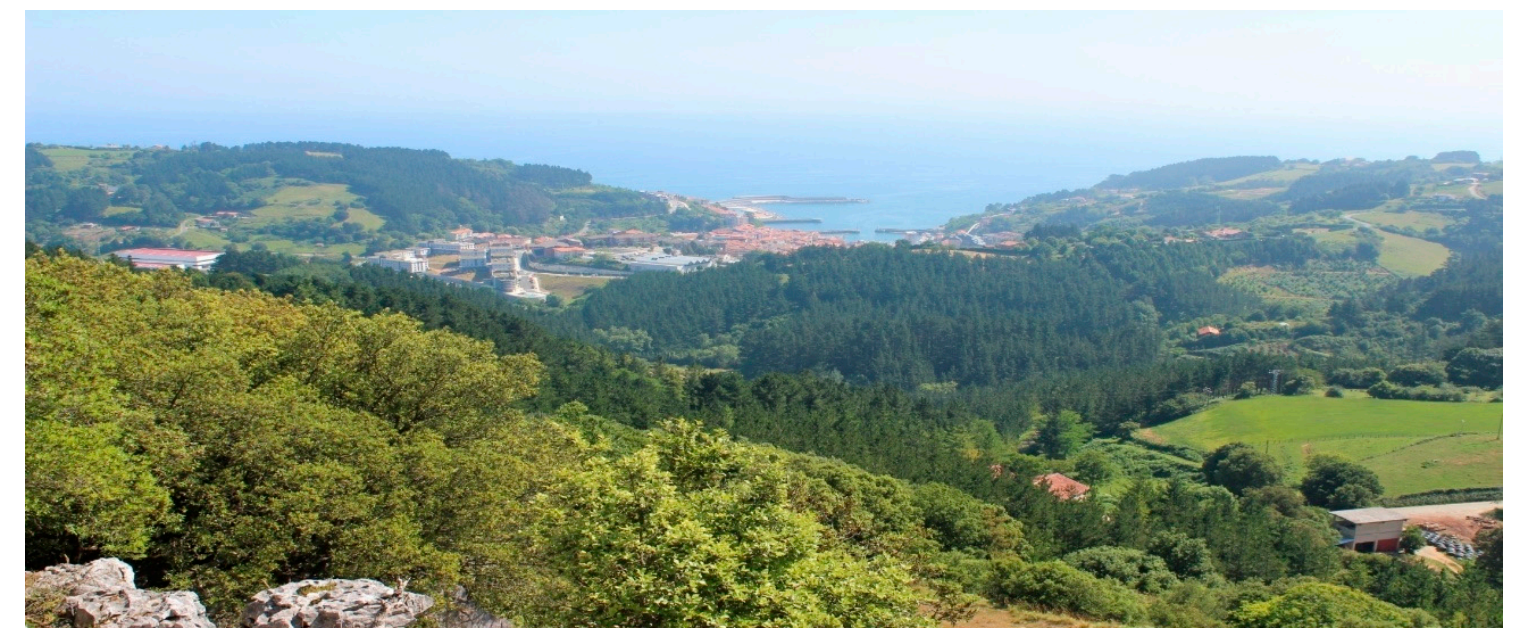

Figure 1. Mutriku coast and rural land.

In this study, an evaluation of rural development alternatives and rural land uses has been carried out. The main problems facing decision-makers in this area are the shortage of land suitable for agriculture, the difficulty of gaining access to it due to urban pressure, and the progressive abandonment of agricultural activity and increase in non-native forest plantations. 
Through the participatory process of the SMCE, three main rural development scenarios were defined [73]: (i) maintaining the current management regimen, business-as-usual scenario; (ii) promoting new sustainable agricultural and livestock models; and (iii) promoting a forestry model based on native species. These three scenarios were specified in five alternatives (Table 1). Each of the alternatives proposes a development model with different uses of rural land.

Table 1. Description of the different development alternatives for rural land.

\begin{tabular}{|c|c|c|}
\hline BAU & A1 & $\begin{array}{l}\text { This alternative reflects the future scenario if the dynamics of the last few decades are } \\
\text { maintained. A gradual reduction in agricultural activity and the maintenance or } \\
\text { proliferation of coniferous forests are foreseen. }\end{array}$ \\
\hline \multirow[t]{2}{*}{ PNAM } & $\mathrm{A} 2 \mathrm{a}$ & $\begin{array}{l}\text { Promote and develop ecological/organic agriculture aimed at new rural and urban markets } \\
\text { that are sensitive to the environment and public health. Recovery of land formerly used for } \\
\text { agriculture, scrub at present. In relation to the forest area, the current policies and uses are } \\
\text { maintained. }\end{array}$ \\
\hline & $\mathrm{A} 2 \mathrm{~b}$ & $\begin{array}{l}\text { Greater promotion and development of farms dedicated to the production of organic and } \\
\text { quality products. Use of soil for agriculture proposed in A2a and larger area. }\end{array}$ \\
\hline \multirow{2}{*}{ PNF } & A3a & $\begin{array}{l}\text { In addition to the agrarian promotion detailed in A2a, the A3a alternative advocates for a } \\
\text { change in forestry policy in favor of a greater area of native species, to the detriment of } \\
\text { non-native species (radiata pine, eucalyptus). The conversion of } 299.9 \text { ha of current } \\
\text { non-native species in the SAC to native species is proposed. }\end{array}$ \\
\hline & $\mathrm{A} 3 \mathrm{~b}$ & $\begin{array}{l}\text { Greater promotion of native species forest. As in the A3a alternative, this alternative is } \\
\text { based on the promotion of new models of agriculture detailed in the A2a alternative. For the } \\
\text { forestry sector, the conversion of non-native species to native species in } 377.7 \text { ha within and } \\
\text { outside the SAC is proposed. }\end{array}$ \\
\hline
\end{tabular}

Source: authors' own compilation. BAU: Business as usual, PNAM: promotion of new agrarian models, PNF: promotion of native forests.

A set of six criteria was agreed to evaluate these scenarios. The criteria are the technical expression of the interests, expectations, and wishes of the social actors, and must represent multiple dimensions of the problem. This set of criteria reflects the economic, ecological, and social aspects of the future of rural land. The criteria considered most important for the evaluation of development plans were the income from agricultural activities, public cost of agricultural subsidies, biodiversity, landscape, rooting to land, and consumption of local products (Table 2); for more details, see [73].

Table 2. Evaluation criteria.

\begin{tabular}{|c|c|c|}
\hline Dimension & Criteria & Definitions; Units of Measurement and Valuation \\
\hline \multirow{2}{*}{ Ecological } & 1. Biodiversity & $\begin{array}{l}\text { Diversity of flora and fauna in rural areas and their quality. } \\
\text { Unit: Index. Valuation: A specific index based on zoogeographic assessments calculated ad hoc } \\
\text { for the studied area. }\end{array}$ \\
\hline & 2. Landscape & $\begin{array}{l}\text { The rural landscape as a social and natural good, valued by society for its ecological and } \\
\text { recreational value. } \\
\text { Unit: Index. Valuation: A specific index based on phytogeographic assessment calculated ad hoc } \\
\text { for the study area. }\end{array}$ \\
\hline \multirow[t]{2}{*}{ Economic } & $\begin{array}{l}\text { 3. Income from } \\
\text { agricultural } \\
\text { activities }\end{array}$ & $\begin{array}{l}\text { Income from agricultural and forestry activities. } \\
\text { Unit: Euros. Valuation: Based on the data offered by the GPC. }\end{array}$ \\
\hline & 4. Public cost & $\begin{array}{l}\text { Aid received by the agricultural sector. } \\
\text { Unit: Euros. Valuation: Based on the data offered by the GPC. }\end{array}$ \\
\hline \multirow{2}{*}{ Social } & $\begin{array}{l}\text { 5. Consumption } \\
\text { of local } \\
\text { products }\end{array}$ & $\begin{array}{l}\text { The consumption in the municipality of agricultural products produced in rural areas. } \\
\text { Unit: Qualitative assessment. Valuation: Based on the information collected in the institutional } \\
\text { analysis and interviews with local agents. }\end{array}$ \\
\hline & $\begin{array}{l}\text { 6. Attachment } \\
\text { to the rural land }\end{array}$ & $\begin{array}{l}\text { Value of culture, traditions and rural know-how. } \\
\text { Unit: Qualitative assessment. Valuation: Based on the information collected in the institutional } \\
\text { analysis and interviews with local agents. }\end{array}$ \\
\hline
\end{tabular}




\subsection{Incorporation of Preferences in the SMCE}

\subsubsection{Identification of Social Actors}

The first step of the participatory process is the selection of actors. In order to carry out a deliberative process, a small group of actors representing all the sensitivities and interests involved in the problem is needed. Four large stakeholder groups were estimated following previous research [52,74]: institutional, technical, economic actors, and representatives of social groups. Within each group, all interests and objectives were to be represented, so that 10 subgroups were identified (Table 3).

Table 3. Participating actors.

\begin{tabular}{|c|c|c|}
\hline & Stakeholders & Aims and Objectives \\
\hline \multirow{3}{*}{ Institutional } & GPC—ecological positions & $\begin{array}{l}\text { Define and implement development policies, } \\
\text { prioritizing ecological objectives }\end{array}$ \\
\hline & GPC—-traditional positions & $\begin{array}{l}\text { Define and implement development policies, economic } \\
\text { and ecological objectives }\end{array}$ \\
\hline & City Council of Mutriku & $\begin{array}{l}\text { Define and implement development policies, } \\
\text { prioritizing employment objectives }\end{array}$ \\
\hline \multirow{3}{*}{ Technical } & Debemen, HAZI, OCA, Geoparke & $\begin{array}{l}\text { Definition of actions and programs aimed at activating } \\
\text { the rural economy and conserving the environment }\end{array}$ \\
\hline & EHNE Labor Union & $\begin{array}{l}\text { Definition of actions and programs aimed at activating } \\
\text { the rural economy }\end{array}$ \\
\hline & ENBA Labor Union & $\begin{array}{l}\text { Definition of actions and programs aimed at activating } \\
\text { the rural economy }\end{array}$ \\
\hline \multirow[b]{2}{*}{ Economic } & Traditional farmers & Obtaining profitability \\
\hline & Innovative farmers & $\begin{array}{l}\text { Obtaining profitability and developing sustainable } \\
\text { agricultural activities }\end{array}$ \\
\hline \multirow{2}{*}{ Social groups } & Ecologist groups & Conservation of the environment and leisure \\
\hline & Leisure groups & Landscape conservation and leisure \\
\hline
\end{tabular}

Source: authors' own compilation.

The identification of the actors began during an institutional analysis and an open meeting, and continued while conducting in-depth interviews by combining the so-called 'snowball sampling method' $[54,75,76]$.

\subsubsection{Participatory Process}

Social participation is a fundamental element of SMCE. To ensure the inclusion of diverse social preferences in the evaluation process, the following activities were conducted:

- A preliminary open meeting to set the scope and methodological framework of the evaluation process (January 2014)

- 32 in-depth personal interviews during the identification phase and subsequent consultations with external experts and authorities (February 2014-May 2015)

- A participatory workshop to define criteria (June 2014)

- A participatory workshop to define different management options (January 2015)

- $\quad$ Final workshop to validate results (July 2016)

In SMCE the information obtained through qualified social participation is an input for the concretization of the problem and the definition of evaluation criteria and possible development alternatives. The exchange of information with social actors begins with the evaluation process and is 
distributed throughout the process by the use of different participatory tools and instruments (in-depth interviews and focus groups in this case).

A total of 32 in-depth interviews were conducted, meeting several times with some of the most representative social actors. The date and time of the interviews were agreed upon according to the preferences and needs of the interviewees, and in all cases the interviewer went to the place proposed by the interviewee, thereby obtaining in-depth knowledge about the interests and expectations of the different social actors. The interviews were conducted following an open and flexible script, and always with a wide margin of time. Two different scripts were designed. The first set out the general research questions, the definition of the problem, the future alternatives, and the most important questions for evaluating these alternatives. The second type of interview was designed for the technical evaluation of certain criteria, and was aimed at technicians and experts in rural development.

Once the team of researchers had concluded the institutional analysis and identified the main problems, in June 2014, the first focus group was organized, aimed at the choice of decision criteria. The meeting began with a presentation on the topics to be dealt with in the order in which they would be worked on. After the presentation, the members of the research team opened up the debate, with the objective that the actors could reflect and allow their opinions to mature. In the second part, the actors were divided into two small groups so that they could express their opinions in a more relaxed and comfortable way [76]. The grouping was carried out as previously planned so that the small groups were heterogeneous and contemplated all the sensitivities present in the process. In each group, two researchers directed the debate. In this focus group, six relevant aspects to be considered for the development of rural land were selected. These aspects form the basis of the evaluation criteria that the research team later defined.

In the second focus group, in January 2015, once the aforementioned criteria had been accepted, the social actors discussed the possible development alternatives proposed by the research team. Following the same procedure as in the first meeting, the research team proposed initial alternatives as a starting point and provided some pictures that were used in the explanation of different alternatives [74,77]. The group was then divided into two small groups to facilitate discussion and reflection. During the debate and the group reflection with social participants, the initial proposal was discarded because it did not reflect the real possibilities in terms of the development of the area, nor the real conflict over underlying land uses. The concrete knowledge that the participants contributed regarding the problem, the possible limitations, and alternatives presented by the area under study led to the modification of the initial approach to development alternatives, substantially modifying the initial approach proposed by the research team. Finally, after some reflection work carried out in the groups, the alternatives were agreed upon.

The chronological order of the focus group was intended to avoid strategies used by stakeholders to defend their own interests [28,78]. Finally, a list of the most important criteria was formed in the first meeting, and possible alternatives for development in the second.

The participating actors were convened for the last time in July 2016 to present the results of the technical evaluation. The purpose of this presentation, in addition to publishing this evaluation, was to gather information for comparison. In this case, it is worth pointing out the different reaction that the technical results provoked among the social actors and the debate and discussion that came up.

\subsubsection{Ranking of Alternatives from the Deliberative Process}

Through a deliberative process carried out for the SMCE, two alternatives emerged as being technically most appropriate, namely alternatives A2b and A3b. According to this evaluation, the worst alternative is to continue with the current dynamics, A1 (see Table 4). 
Table 4. Ranking of alternatives.

\begin{tabular}{l}
\hline Ranking of Alternatives According to Their Degree of Suitability \\
\hline Most suitable alternatives:___ A $2 \mathrm{~b} \_$A $3 \mathrm{~b}$ \\
\hline Second most suitable alternatives:__ A $2 \mathrm{a} \_$A $3 \mathrm{a}$ \\
\hline Least suitable alternative:__ A 1 \\
\hline Source: authors' own compilation.
\end{tabular}

In addition to the technical evaluation, SMCE carries out a social evaluation whereby the position of social actors is analyzed in relation to the different alternatives, along with the risk of conflict presented by each of them. For this, the possible coalitions that can be created, as well as the ranking of preference of each group of actors, are assessed.

Table 5 shows that, of the two technically most suitable alternatives, alternative A3b was favored by the majority of the identified social actors (i.e., the GPC's ecological positions, rural development agencies, social stakeholder groups, and innovative farmers). However, alternative A3b was ranked lowest according to the preferences of the group of social actors formed by the traditional positions of public institutions and traditional farmers, and the second worst for agrarian unions. It should be noted that, despite being small groups, they represent the timber industry and rural land ownership, so they influence decisions significantly. The $\mathrm{A} 2 \mathrm{~b}$ alternative shows greater acceptance among different social groups and, therefore, a lower risk of conflict.

Table 5. Coalitions of social actors and their preferences on alternatives.

\begin{tabular}{cccc}
\hline & \multicolumn{3}{c}{ Coalitions of social actors } \\
\cline { 2 - 4 } Preference Level & EHNE Labor Union \& & $\begin{array}{c}\text { Provincial Council of } \\
\text { Gipuzkoa-traditional } \\
\text { positions \& }\end{array}$ & $\begin{array}{c}\text { Provincial Council of } \\
\text { Gipuzkoa-ecological positions, } \\
\text { Mutriku Town Council }\end{array}$ \\
\cline { 2 - 4 } ENBA Labor Union & Traditional farmers & $\begin{array}{c}\text { Debemen, Regional Agricultural } \\
\text { Office, Geopark, HAZI, innovative } \\
\text { farmers, ecological groups, leisure } \\
\text { and sports associations }\end{array}$ \\
\hline High & A 2b & A 2a & A 3b \\
\cline { 2 - 4 } & A 2a & A 2b & A 3a \\
\cline { 2 - 4 } & A 3a & A 1 & A 2b \\
\hline & A 3b & A 3a & A 2a 1 \\
\hline
\end{tabular}

\subsection{Incorporation of Preferences through a Survey Approach}

Once we had developed the SMCE, we tested the results obtained in the participatory process with a survey developed with a representative sample of citizens in Mutriku. Data were collected during November 2015. Taking as a reference the population of 5325 inhabitants, a random sample of 262 persons residing in the municipality was selected. The survey was segmented according to age, sex, study level, and area of residence (rural-urban) based on the interest that this segmentation presents for the environmental decisions (Appendix A).

The questionnaire was structured in three sections. The first section focuses on the socioeconomic characteristics of Mutriku; the second section investigates the awareness of the evaluation criteria; the third section aims to measure Mutriku citizens' preference towards the possible alternatives defined through SMCE. 
Individual Preferences: Acceptance of Criteria and Ranking of Alternatives

The awareness of the criteria selected through SMCE was measured by asking Mutriku's citizens, using a Likert scale of 0 to 10 (where 0 indicates low importance and 10 very high importance). Thus, we can see that all the criteria have a similar valuation. However, the criterion that represents Landscape presents the highest average score, at 8.57, followed by Local Consumption and Attachment to the Rural Land with scores of 8.39 and 8.13, respectively (Appendix B).

On the other hand, an index has been created to classify on different scales the level of acceptance of the criteria [79]. This analysis indicates that the six criteria have the same acceptance level, which is quite good (Table 6).

Table 6. Level of acceptance of six criteria.

\begin{tabular}{cccccc}
\hline \multirow{2}{*}{ Criteria } & \multirow{2}{*}{ Score } & \multicolumn{5}{c}{ Category } \\
\cline { 3 - 6 } & & Not Good & Not Very Good & Quite Good & Very Good \\
\hline Biodiversity & $0-80$ & $X$ & $X$ & 63.12 & $X$ \\
\hline Landscape & $0-30$ & $X$ & $X$ & 25.71 & $X$ \\
\hline Agrarian income & $0-90$ & $X$ & $X$ & 29.12 & $X$ \\
\hline Public cost & $0-40$ & $X$ & $X$ & 50.34 & $X$ \\
\hline Local Consumption & $0-60$ & $X$ & $X$ & 48.78 & $X$ \\
\hline Attachment to the Rural Land & $0-60$ & $X$ & $X$ & &
\end{tabular}

Therefore, as far as the evaluation criteria are concerned, the results of the consultation of the entire population agree with the set of criteria selected through the deliberative process.

In relation to the preferences for future alternatives, the alternative that proposes new agricultural models and the high potentiation of the native forest, the A3b alternative, has been evaluated as the best in general. On the other hand, the alternative of maintaining current dynamics, alternative A1, is evaluated as the worst scenario (see Table 7).

Table 7. Averages of the alternatives of the rural land of Mutriku.

\begin{tabular}{ccc}
\hline & \multicolumn{2}{c}{ General } \\
\hline Alternatives & Mean & Standard Deviation \\
\hline A1 & 6.42 & 1.931 \\
\hline A2a & 7.42 & 1.482 \\
\hline A2b & 7.10 & 1.872 \\
\hline A3a & 7.74 & 1.590 \\
\hline A3b & $\mathbf{8 . 2 3}$ & 1.859 \\
\hline N valid (per list) & 255 & \\
\hline Source: authors' own compilation. Data processing: SPSS v.24.
\end{tabular}

As Table 7 shows, the result coincides in part with the analysis carried out through the deliberative processes. The future alternative chosen by the general population coincides with one of the two alternatives selected through the deliberative process, i.e., with the one with the greatest ecological value. However, this alternative, technically one of the most suitable according to EMCS, presents a high degree of risk of conflict, and the social group composed of rural landowners and the timber industry do not tolerate it.

To complete the analysis, we consider it interesting to analyze the ranking of alternatives according to the place of residence of those surveyed, dividing the sample between rural and urban inhabitants 
(Table 8). This classification allows us to observe the different preferences between the population directly affected by the management of the place in which they live and the rest of the urban population.

Table 8. Averages of the alternatives of the rural land of Mutriku for rural and urban population.

\begin{tabular}{ccccc}
\hline & \multicolumn{2}{c}{ Urban } & \multicolumn{2}{c}{ Rural } \\
\hline Alternatives & Mean & Standard Deviation & Mean & Standard Deviation \\
\hline A1 & 6.52 & 1.991 & 5.87 & 1.454 \\
\hline A2a & 7.34 & 1.501 & 7.85 & 1.309 \\
\hline A2b & 7.18 & 1.779 & 6.69 & 2.307 \\
\hline A3a & 7.77 & 1.581 & 7.59 & 1.650 \\
\hline A3b & $\mathbf{8 . 1 3}$ & 1.856 & $\mathbf{8 . 7 9}$ & 1.794 \\
\hline N valid (per list) & 216 & & 39 \\
\hline
\end{tabular}

If we analyze the preferences of the urban and rural population separately, it can be seen that for both population groups the best alternative is A3b, the alternative that proposes new agricultural models and the high potentiation of the native forest. The rural population of Mutriku surveyed values it more highly than the urban population of the same municipality. On the other hand, the worst scenario is A1 for the two samples, the alternative of maintaining the current dynamics. The value of the rural individual is lower than that of the urban individual (see Table 8).

In order to study whether there are differences between the values assigned to the alternatives proposed by the different audiences, a Mann-Whitney $U$ test analysis has been carried out for each alternative (see Table 9).

Table 9. Mann-Whitney U test for two independent samples.

\begin{tabular}{cccc}
\hline Alternative & N $^{\text {C }}$ Cases & Mann-Whitney's U & Sig. Asymptotic (Bilateral) \\
\hline A1 & $\begin{array}{c}218 \\
39\end{array}$ & 3075.50 & 0.005 \\
\hline A2a & $\begin{array}{c}217 \\
39\end{array}$ & 3549.5 & 0.102 \\
\hline A2b & $\begin{array}{c}219 \\
39\end{array}$ & 3868 & 0.341 \\
\hline A3a & $\begin{array}{c}219 \\
39\end{array}$ & 4062 & 0.617 \\
\hline \multirow{2}{*}{ A3b } & $\begin{array}{c}219 \\
39\end{array}$ & 3207 & 0.011 \\
\hline & Source: authors' own compilation. Data processing: SPSS v.24.
\end{tabular}

In this case, the null hypothesis of equality of means for alternatives $\mathrm{A} 2 \mathrm{a}, \mathrm{A} 2 \mathrm{~b}$, and $\mathrm{A} 3 \mathrm{a}$ is not rejected as the level of significance reached is higher than the usual minimum of $p>0.05$. Therefore, we can affirm that there are no significant differences between the average values assigned by urban and rural people to these three alternatives. However, for alternatives A1 and A3b the differences in the averages presented are significant.

If we contrast this information with that obtained in the deliberative process, it can be seen that the position of the majority of residents in the rural land does not coincide with that shown by the owners of the land during the deliberative process, which indicates that these two social groups are not made up of the same people. 


\section{Discussion}

Considering and including different points of view on, and interests in, natural resource management processes remains a challenge for achieving sustainable solutions. This is why the multi-criteria methodology has evolved to consider social participation a key element. However, among the different participatory approaches, deliberative processes, based on deliberative democracy principles, and statistical methods based on samples of the entire population are often presented as alternative approaches. In this work, to explore this issue we have compared two participatory processes: on the one hand, a deliberative process, and on the other hand, a survey of the population.

We can conclude that both the results and the information obtained during the evaluation process differ according to the applied participatory methodology, but, most of all, it is observed that the information obtained through these two participatory approaches can be complementary and mutually beneficial for achieving efficient processes.

With regard to the results coming from the participatory process, it can be observed that in the deliberative processes the social actors interact multiple times, with time and calm for reflection, enabling them to allow their opinions to mature and develop their own and mutual learning processes. This has allowed participants to question preconceived ideas and, through dialogue, discussion, and the exchange of knowledge, form new opinions, and have their social preferences formed by the group. The joint creation of social preferences has been evident in the case of the formulation of alternatives, where the initial alternatives proposed by the research team were discussed and totally reformulated during the focus group, overcoming the excessive influence attributed to these proposals [12,21,48]. The alternatives finally agreed upon have been the product of group deliberation, worked on and defined jointly between heterogeneous actors and the research team. Therefore, in this case it can be said that the reflection and debate in groups has allowed for the creation of social preferences.

By contrast, it is also observed that in survey participation, the limitation on the time for reflection itself, as well as the lack of additional information on issues that are unknown or on which there is no previous opinion, may be a significant constraint when issuing an opinion. Thus, the surveys do not consider the possibility of reformulating the proposals, limiting the answers to the questions previously raised. The creation of new proposals derived from a learning process is non-existent in these cases, thereby reducing the range of possible solutions.

In addition to the results themselves, the information provided by the various participatory processes is of a very different nature. On the one hand, when participation is open to the totality of the population affected by the issue in question, the representation of all visions and sensitivities is guaranteed. Hence, the participatory process includes sufficient information to guarantee the quality of the agreements, as well as their legitimacy through citizen endorsement. In terms of the information collected, the statistical methods applied to large samples allow for analysis by segments and can obtain information on the positioning of different sectors of society in the face of the same problem. In environmental decisions, knowing the position of the different generations, or of the urban and rural population, can be extremely interesting for political decision-making. By contrast, in deliberative participatory processes the group of participants is a preselected group and too small to be able to obtain information on different segments of society. Thus, the selection of participating actors must be done in such a way that the different interests and visions are represented in the process.

On the other hand, throughout the deliberative participatory process and during the debates and periods of reflection, the actors position themselves before the different alternatives considered. This allows us to observe the potential winners and losers before these alternatives, as well as their reactions, and the possible conflicts that can be generated. This qualitative information makes it possible to foresee conflicts and responses to distant decisions, which is an important element for the development of public policies.

Thus, deliberative processes make it possible to observe the different force and influence that different stakeholder groups can exert, both during the process and in the agreements reached $[16,51,67,80,81]$. It is possible for some stakeholders to participate with the sole objective 
of defending their own interests, without any interest in providing information or enriching the process [51]. In our case, we have seen that the asymmetries of stakeholders' strength and influence have been important in providing information on possible future conflicts and the political and economic strength that each stakeholder group can bring to different political decisions.

Finally, the problem of representation came up during the deliberative process. The deliberative processes must confront the problem of scale [60] and select a reduced number of participants, taking into consideration all the interest in, and visions on, the treated problem. In addition, participants must be able and willing to participate effectively. The quality and legitimacy of the deliberative process and its results therefore depend to a large extent on the appropriate selection of participants. In this regard, the representation of citizenship is a controversial and widely analyzed issue [49,51]. In our case, the results obtained through the two participatory methods indicate that in the deliberative process the representation of citizenship through stakeholders from organized social groups may not be sufficient.

It was supposed that, due to stakeholders representing social and leisure groups, the opinion of citizens was sufficiently represented. However, the contrast with the results of the survey of the entire population indicates that the opinion of a large part of the population may not be reflected in the deliberative processes, or at least not sufficiently represented by adopted stakeholders. Therefore, it is not clear whether the greater representation of citizens, through random representatives or stakeholders representing a wider range of social groups, on the one hand, would have improved the quality of the process, or, on the other hand, whether the results would have been the same with these new participants.

\section{Conclusions}

This paper addresses the question of the different frameworks of social participation in multi-criteria decisions on the management of natural resources.

The validity of the two participatory frameworks has been verified. On the one hand, a survey investigated important quantitative information about the acceptance of evaluation criteria and the opinion of citizenship about alternatives for the future, segmenting the different opinions of the sectors of society. On the other hand, a deliberative process has been verified in the creation of social preferences and in providing information about the acceptance of different social groups and the risk of conflict of certain alternatives. However, the problem of representativeness in the deliberative processes continues to raise certain unresolved issues.

So, from this work we can conclude that social participation through deliberative processes and participation through statistical methods provide different and complementary information, which can contribute to the quality and efficiency of environmental decision-making processes. Thus, in multi-criteria evaluation, contrasting deliberate participatory methods with survey participation can greatly enrich decision-making processes.

Author Contributions: All authors contributed to the manuscript. Conceptualization, I.B.-R., A.E.-T., P.J.L. and I.L.; Data curation, A.E.-T.; Formal analysis, I.B.-R. and A.E.-T.; Funding acquisition, P.J.L.; Investigation, I.B.-R., P.J.L. and I.L.; Methodology, I.B.-R. and A.E.-T.; Project administration, P.J.L.; Writing-original draft, I.B.-R. and A.E.-T.; Project administration, P.J.L.; Writing—original draft, I.B.-R. and A.E.-T.; writing-review and editing, I.B.-R. and A.E.-T.; supervision, I.B.-R. and A.E.-T.

Funding: This research has received funding from the UPV/EHU GIU 10/07 project.

Acknowledgments: The authors wish to thank all the stakeholders interviewed and surveyed for their participation.

Conflicts of Interest: The authors declare no conflict of interest. The funders had no role in the design of the study; in the collection, analyses, or interpretation of data; in the writing of the manuscript, or in the decision to publish the results.

\section{Appendix A -Descriptive Statistics on Socio-Economic Variables}

Table A1 provides descriptive statistics for the study's socio-economic variables. The average age (50.15 years) and gender (53\% male and $47 \%$ female) of respondents are in line with the average age 
and gender breakdown of the Mutriku population. The other two explanatory variables considered in the survey have been STUDIES (for the level of education of the respondent, 1 is the lowest level and 6 the highest) and AREA of residence (takes the value 1 if the respondent lives in an urban area and 2 if the respondent lives in a rural area).

As this study focuses on the effect of the AREA of residence variable, the relationship between this variable and the other socio-economic variables was analyzed in more detail. If the AREA variable shares a large amount of information with another socio-economic variable (for example, if people living in rural areas also have a higher level of education, or if a large part of the rural population is male), the estimated coefficient for the AREA variable could capture the effect of another variable (possibly) not included in the final model. Therefore, we carried out a T-test for the difference between urban and rural means for the variables AGE and STUDIES. The p-values in Table 1 suggest that the null hypothesis of equal averages cannot be rejected. On the other hand, the correlation between the AREA variable and the SEX variable was analyzed in parallel by using the Spearman contingency coefficient. This method provides an easily interpretable measure of the degree of association between two variables based on the standard chi-square test for determining independence. As shown in the last column of Table A1, this 0-1 coefficient demonstrates a weak correlation between AREA and GENDER.

Table A1. Descriptive statistics.

\begin{tabular}{ccccccccc}
\hline & Mean & Min & Max & Included & Excluded Cases & Std. Dev. & T-Test & Spearman \\
\hline SEX & 1.53 & 1 & 2 & 262 & 0 & 0.500 & -0.101 \\
\hline AGE & 50.15 & 18 & 90 & 262 & 0 & 16.442 & 0.388 \\
\hline STUDIES & 3.79 & 1 & 6 & 257 & 5 & 1.586 & -1.531 \\
\hline AREA & 1.15 & 1 & 2 & 262 & 0 & 0.357 & \\
\hline \multicolumn{7}{c}{ Source: own elaboration. Data processing: SPSS v.24. }
\end{tabular}

\section{Appendix B -Acceptance of Criteria}

For the six evaluation criteria, the answers to the corresponding survey questions were combined by performing a factor analysis into six single factors. As shown in Table A2, on the one hand, the degree to which dimensional items are correlated to each other is measured by the value of Cronbach's $\alpha$ and exceeds the recommended value of 0.7 [82]. On the other hand, the composite reliability index, which is greater than 0.6 for all factors, exceeds the minimum value recommended by [83]. Moreover, we calculated the average score for each dimension using an approach applied by [79].

Table A2. Factor analysis for evaluation criteria of Mutriku's rural area.

\begin{tabular}{|c|c|c|c|c|c|c|c|}
\hline Criteria & Items & Mean & Standard Deviation & Factorial Loads & Cronbach's $\alpha$ & $\begin{array}{c}\text { Composite } \\
\text { Reliability Index }\end{array}$ & Average Levels \\
\hline \multirow{9}{*}{$\begin{array}{l}\text { Agrarian income } \\
\quad(9 \text { items })\end{array}$} & P204 & 7.86 & 1.556 & 0.768 & \multirow{9}{*}{0.697} & \multirow{9}{*}{0.813} & \multirow{9}{*}{7.68} \\
\hline & P205 & 7.63 & 1750 & 0.781 & & & \\
\hline & P206 & 6.63 & 2.593 & 0.055 & & & \\
\hline & P207 & 7.88 & 1.606 & 0.674 & & & \\
\hline & P208 & 8.44 & 1.504 & 0.696 & & & \\
\hline & P209 & 7.41 & 2.178 & 0.418 & & & \\
\hline & P210 & 7.98 & 1.742 & 0.660 & & & \\
\hline & P211 & 8.13 & 1.478 & 0.729 & & & \\
\hline & P212 & 7.18 & 2.162 & 0.278 & & & \\
\hline
\end{tabular}


Table A2. Cont.

\begin{tabular}{|c|c|c|c|c|c|c|c|}
\hline Criteria & Items & Mean & Standard Deviation & Factorial Loads & Cronbach's $\alpha$ & $\begin{array}{c}\text { Composite } \\
\text { Reliability Index }\end{array}$ & Average Levels \\
\hline \multirow{6}{*}{$\begin{array}{l}\text { Local Consumption } \\
\quad(6 \text { items })\end{array}$} & P213 & 8.30 & 1.340 & 0.857 & \multirow{6}{*}{0.798} & \multirow{6}{*}{0.881} & \multirow{6}{*}{8.39} \\
\hline & P214 & 8.55 & 1.204 & 0.839 & & & \\
\hline & P215 & 8.59 & 1.227 & 0.831 & & & \\
\hline & P216 & 8.56 & 1.319 & 0.802 & & & \\
\hline & P217 & 8.47 & 1.380 & 0.802 & & & \\
\hline & P218 & 7.85 & 1.815 & 0.209 & & & \\
\hline \multirow{6}{*}{$\begin{array}{l}\text { Attachment to the } \\
\text { rural land } \\
\text { (6 items) }\end{array}$} & P219 & 8.08 & 1.734 & 0.356 & \multirow{6}{*}{0.767} & \multirow{6}{*}{0.85} & \multirow{6}{*}{8.13} \\
\hline & P220 & 8.34 & 1.352 & 0.736 & & & \\
\hline & P221 & 7.15 & 1.934 & 0.740 & & & \\
\hline & $\mathrm{P} 222$ & 8.22 & 1.338 & 0.848 & & & \\
\hline & P223 & 8.11 & 1.412 & 0.803 & & & \\
\hline & P224 & 8.85 & 1.143 & 0.645 & & & \\
\hline \multirow{8}{*}{$\begin{array}{l}\text { Biodiversity } \\
\text { (8 items) }\end{array}$} & P225 & 8.47 & 1.471 & 0.502 & \multirow{8}{*}{0.732} & \multirow{8}{*}{0.822} & \multirow{8}{*}{7.89} \\
\hline & P226 & 7.91 & 1.402 & 0.665 & & & \\
\hline & P227 & 7.42 & 2.086 & 0.527 & & & \\
\hline & P228 & 6.71 & 2.517 & 0.466 & & & \\
\hline & P229 & 7.83 & 1.597 & 0.610 & & & \\
\hline & P230 & 8.38 & 1.274 & 0.679 & & & \\
\hline & $\mathrm{P} 231$ & 8.20 & 1.521 & 0.666 & & & \\
\hline & P232 & 8.24 & 1.809 & 0.709 & & & \\
\hline \multirow{3}{*}{$\begin{array}{l}\text { Landscape } \\
\text { (3 items) }\end{array}$} & P233 & 8.76 & 1.341 & 0.817 & \multirow{3}{*}{0.718} & \multirow{3}{*}{0.843} & \multirow{3}{*}{8.57} \\
\hline & $\mathrm{P} 234$ & 8.34 & 1.558 & 0.808 & & & \\
\hline & P235 & 8.63 & 1.320 & 0.774 & & & \\
\hline \multirow{4}{*}{$\begin{array}{l}\text { Public Cost } \\
\text { (4 items) }\end{array}$} & P237 & 6.34 & 1.859 & 0.829 & \multirow{4}{*}{0.781} & \multirow{4}{*}{0.858} & \multirow{4}{*}{7.33} \\
\hline & P238 & 7.07 & 1.753 & 0.800 & & & \\
\hline & P239 & 7.15 & 1.401 & 0.675 & & & \\
\hline & P240 & 8.18 & 1.646 & 0.794 & & & \\
\hline
\end{tabular}

Source: own elaboration. Data processing: SPSS v.24. Extraction method: analysis of main components.

\section{References}

1. Funtowicz, S.O.; Ravetz, J.R. The worth of a songbird: Ecological economics as a post-normal science. Ecol. Econ. 1994, 10, 197-207. [CrossRef]

2. Martínez-Alier, J.; Munda, G.; O’Neill, J. Weak comparability of values as a foundation for ecological economics. Ecol. Econ. 1998, 26, 277-286. [CrossRef]

3. Munda, G. Social Multi-Criteria Evaluation for a Sustainable Economy; Springer: BerlinHeidelberg, Germany, 2008; Volume 17.

4. Munda, G. Social multi-criteria evaluation: Methodological foundations and operational consequences. Eur. J. Oper. Res. 2004, 158, 662-677. [CrossRef]

5. O'Neill, J. Representing people, representing nature, representing the world. Environ. Plan. C Gov. Policy 2001, 19, 483-500. [CrossRef]

6. Martínez-Sastre, R.; Ravera, F.; González, J.; Santiago, C.L.; Bidegain, I.; Munda, G. Mediterranean landscapes under change: Combining social multicriteria evaluation and the ecosystem services framework for land use planning. Land Use Policy 2017, 67, 472-486. [CrossRef]

7. Etxano, I.; Garmendia, E.; Pascual, U.; Hoyos, D.; Díez, M.; Cadiñanos, J.A.; Lozano, P.J. A participatory integrated assessment approach for Natura 2000 network sites. Environ. Plan. C Gov. Policy 2015, 33, 1207-1232. [CrossRef]

8. Harremoës, P.; Turner, R. Methods for integrated assessment. Reg. Environ. Chang. 2001, 2, 57-65. [CrossRef]

9. Wegner, G.; Pascual, U. Cost-benefit analysis in the context of ecosystem services for human well-being: A multidisciplinary critique. Glob. Environ. Chang. 2011, 21, 492-504. [CrossRef]

10. Giampietro, M.; Mayumi, K.; Munda, G. Integrated assessment and energy analysis: Quality assurance in multi-criteria analysis of sustainability. Energy 2006, 31, 59-86. [CrossRef] 
11. Antunes, P.; Kallis, G.; Videira, N.; Santos, R. Participation and Evaluation for Sustainable River Basin Governance. Ecol. Econ. 2009, 68, 931-939. [CrossRef]

12. Stagl, S. Multicriteria evaluation and public participation: The case of UK energy policy. Land Use Policy 2006, 23, 53-62. [CrossRef]

13. Videira, N.; Antunes, P.; Santos, R. Scoping river basin management issues with participatory modelling: The Baixo Guadiana experience. Ecol. Econ. 2009, 68, 965-978. [CrossRef]

14. Wittmer, H.; Rauschmayer, F.; Klauer, B. How to select instruments for the resolution of environmental conflicts? Land Use Policy 2006, 23, 1-9. [CrossRef]

15. Renn, O.; Webler, T.; Rakel, H.; Dienel, P.; Johnson, B. Public participation in decision making: A three-step procedure. Policy Sci. 1993, 26, 189-214. [CrossRef]

16. Renn, O. Participatory processes for designing environmental policies. Land Use Policy 2006, 23, 34-43. [CrossRef]

17. Soma, K. Framing participation with multicriterion evaluations to support the management of complex environmental issues. Environ. Policy Gov. 2010, 20, 89-106. [CrossRef]

18. Munda, G.; Nijkamp, P.; Rietveld, P. Qualitative multicriteria methods for fuzzy evaluation problems: An illustration of economic-ecological evaluation. Eur. J. Oper. Res. 1995, 82, 79-97. [CrossRef]

19. Gamper, C.D.; Turcanu, C. On the governmental use of multi-criteria analysis. Ecol. Econ. 2007, 62, $298-307$. [CrossRef]

20. Roy, B. Paradigms and challenges. In Multiple Criteria Decision Analysis: State of the Art Surveys; Figueira, J., Greco, S., Ehrgott, M., Eds.; Springer: Berlin/Heidelberg, Germany, 2005; pp. 3-24.

21. Dean, M.; Hickman, R.; Chen, C. Testing the application of participatory MCA: The case of the South Fylde Line. Transp. Policy 2019, 73, 62-70. [CrossRef]

22. Vatn, A. An institutional analysis of methods for environmental appraisal. Ecol. Econ. 2009, 68, $2207-2215$. [CrossRef]

23. Videira, N.; Antunes, P.; Santos, R.; Lobo, G. Public and stakeholder participation in European water policy: A critical review of project evaluation processes. Environ. Policy Gov. 2006, 16, 19-31. [CrossRef]

24. Zografos, C.; Rodríguez, B. Economic Tools for Evaluating Liabilities in Environmental Justice Struggles, the EJOLT Experience. 2014. Available online: http://www.ejolt.org/wordpress/wp-content/uploads/2014/10/ EJOLT_Report_16.pdf (accessed on 16 October 2019).

25. Zografos, C.; Howarth, R.B. Deliberative ecological economics for sustainability governance. Sustainability 2010, 2, 3399-3417. [CrossRef]

26. Lynam, T.; De Jong, W.; Sheil, D.; Kusumanto, T.; Evans, K. A Review of Tools for Incorporating Community Knowledge, Preferences, and Values into Decision Making in Natural Resources Management. 2007. Available online: https://www.ecologyandsociety.org/vol12/iss1/art5/main.html (accessed on 16 October 2019).

27. Carnoye, L.; Lopes, R. Participatory Environmental Valuation: A Comparative Analysis of Four Case Studies. Sustainability 2015, 7, 9823-9845. [CrossRef]

28. Garmendia, E.; Stagl, S. Public participation for sustainability and social learning: Concepts and lessons from three case studies in Europe. Ecol. Econ. 2010, 69, 1712-1722. [CrossRef]

29. Kok, K.; van Vliet, M.; Bärlund, I.; Dubel, A.; Sendzimir, J. Combining participative backcasting and exploratory scenario development: Experiences from the SCENES project. Technol. Forecast. Soc. Chang. 2011, 78, 835-851. [CrossRef]

30. Partidário, M.R.; Sheate, W.R.; Bina, O.; Byron, H.; Augusto, B. Sustainability assessment for agriculture scenarios in Europe's mountain areas: Lessons from six study areas. Environ. Manag. 2009, 43, 144-165. [CrossRef]

31. Raymond, C.M.; Kenter, J.O.; Plieninger, T.; Turner, N.J.; Alexander, K.A. Comparing instrumental and deliberative paradigms underpinning the assessment of social values for cultural ecosystem services. Ecol. Econ. 2014, 107, 145-156. [CrossRef]

32. Stringer, L.; Dougill, A.; Fraser, E.; Hubacek, K.; Prell, C.; Reed, M. Unpacking "participation" in the adaptive management of social-ecological systems: A critical review. Ecol. Soc. 2006, 11, 39. [CrossRef]

33. Zionts, S.; Wallenius, J. An interactive programming method for solving the multiple criteria problem. Manag. Sci. 1976, 22, 652-663. [CrossRef] 
34. Banville, C.; Landry, M.; Martel, J.; Boulaire, C. A stakeholder approach to MCDA. Syst. Res. Behav. Sci. 1998, 15, 15-32. [CrossRef]

35. De Marchi, B.; Funtowicz, S.; Cascio, S.L.; Munda, G. Combining participative and institutional approaches with multicriteria evaluation. An empirical study for water issues in Troina, Sicily. Ecol. Econ. 2000, 34, 267-282. [CrossRef]

36. Proctor, W. MCDA and stakeholder participation: Valuing forest resources. In Alternatives for Environmental Valuation; Routledge: Abingdon, UK, 2005; pp. 150-174.

37. Roy, B. Méthodologie Multicritère D'aide à la Décision. 1985. Available online: https://www.persee.fr/doc/ pomap_0758-1726_1986_num_4_3_1906_t1_0138_0000_1 (accessed on 16 October 2019).

38. Gamboa, G.; Munda, G. The problem of windfarm location: A social multi-criteria evaluation framework. Energy Policy 2007, 35, 1564-1583. [CrossRef]

39. Hajkowicz, S.; Collins, K. Measuring the benefits of environmental stewardship in rural landscapes. Landsc. Urban Plann. 2009, 93, 93-102. [CrossRef]

40. Liu, S.; Proctor, W.; Cook, D. Using an integrated fuzzy set and deliberative multi-criteria evaluation approach to facilitate decision-making in invasive species management. Ecol. Econ. 2010, 69, 2374-2382. [CrossRef]

41. Monterroso, I.; Binimelis, R.; Rodríguez-Labajos, B. New methods for the analysis of invasion processes: Multi-criteria evaluation of the invasion of Hydrilla verticillata in Guatemala. J. Environ. Manag. 2011, 92, 494-507. [CrossRef]

42. Roca, E.; Gamboa, G.; Tàbara, J.D. Assessing the multidimensionality of coastal erosion risks: Public participation and multicriteria analysis in a Mediterranean coastal system. Risk Anal. 2008, 28, 399-412. [CrossRef]

43. Fiorino, D.J. Citizen participation and environmental risk: A survey of institutional mechanisms. Sci. Technol. Hum. Values 1990, 15, 226-243. [CrossRef]

44. Reed, M.S.; Graves, A.; Dandy, N.; Posthumus, H.; Hubacek, K.; Morris, J.; Prell, C.; Quinn, C.H.; Stringer, L.C. Who's in and why? A typology of stakeholder analysis methods for natural resource management. J. Environ. Manag. 2009, 90, 1933-1949. [CrossRef]

45. Rauschmayer, F.; Berghöfer, A.; Omann, I.; Zikos, D. Examining processes or/and outcomes? Evaluation concepts in European governance of natural resources. Environ. Policy Gov. 2009, 19, 159-173. [CrossRef]

46. Schultz, L.; Duit, A.; Folke, C. Participation, adaptive co-management, and management performance in the world network of biosphere reserves. World Dev. 2011, 39, 662-671. [CrossRef]

47. Funtowicz, S.O.; Ravetz, J.R. Uncertainty and Quality in Science for Policy; Springer Science \& Business Media: Berlin/Heidelberg, Germany, 1990; Volume 15.

48. Mavrommati, G.; Borsuk, M.; Howarth, R. A novel deliberative multicriteria evaluation approach to ecosystem service valuation. Ecol. Soc. 2017, 22, 39. [CrossRef]

49. Davies, B.B.; Blackstock, K.; Rauschmayer, F. 'Recruitment','composition', and 'mandate'issues in deliberative processes: Should we focus on arguments rather than individuals? Environ. Plan. C Gov. Policy 2005, 23, 599-615. [CrossRef]

50. Johnson, H.; Wilson, G. Biting the bullet: Civil society, social learning and the transformation of local governance. World Dev. 2000, 28, 1891-1906. [CrossRef]

51. Soma, K.; Vatn, A. Is there anything like a citizen? A descriptive analysis of instituting a citizen's role to represent social values at the municipal level. Environ. Policy Gov. 2010, 20, 30-43. [CrossRef]

52. Kok, K.; Biggs, R.O.; Zurek, M. Methods for developing multiscale participatory scenarios: Insights from southern Africa and Europe. Ecol. Soc. 2007, 12, 355506. [CrossRef]

53. Wollenberg, E.; Edmunds, D.; Buck, L. Using scenarios to make decisions about the future: Anticipatory learning for the adaptive co-management of community forests. Landsc. Urban Plan. 2000, 47, 65-77. [CrossRef]

54. Garmendia, E.; Gamboa, G. Weighting social preferences in participatory multi-criteria evaluations: A case study on sustainable natural resource management. Ecol. Econ. 2012, 84, 110-120. [CrossRef]

55. Arrow, K.J. Social Choice and Individual Values; Yale University Press: New Haven, CT, USA, 2012; Volume 12.

56. Zografos, C.; Howarth, R. Deliberative Ecological Economics; Oxford University Press: Oxford, UK, 2008.

57. Brown, G. Public participation GIS (PPGIS) for regional and environmental planning: Reflections on a decade of empirical research. J. Urban Reg. Inf. Syst. Assoc. 2012, 25, 7-18. 
58. Kenter, J.O.; O’Brien, L.; Hockley, N.; Ravenscroft, N.; Fazey, I.; Irvine, K.N.; Reed, M.S.; Christie, M.; Brady, E.; Bryce, R. What are shared and social values of ecosystems? Ecol. Econ. 2015, 111, 86-99. [CrossRef]

59. Habermas, J. The Theory of Communicative Action: Jurgen Habermas; McCarthy, T., Translator; Beacon Press: Boston, MA, USA, 1984.

60. Dryzek, J.S. Deliberative Democracy and Beyond: Liberals, Critics, Contestations; Oxford University Press: Oxford, UK, 2002.

61. Kenter, J.O.; Hyde, T.; Christie, M.; Fazey, I. The importance of deliberation in valuing ecosystem services in developing countries-Evidence from the Solomon Islands. Glob. Environ. Chang. 2011, 21, 505-521. [CrossRef]

62. Lienhoop, N.; Völker, M. Preference refinement in deliberative choice experiments for ecosystem service valuation. Land Econ. 2016, 92, 555-577. [CrossRef]

63. Proctor, W.; Drechsler, M. Deliberative multicriteria evaluation. Environ. Plan. C Gov. Policy 2006, 24, 169-190. [CrossRef]

64. Murphy, M.; Mavrommati, G.; Mallampalli, V.; Howarth, R.; Borsuk, M. Comparing group deliberation to other forms of preference aggregation in valuing ecosystem services. Ecol. Soc. 2017, 22, 17. [CrossRef]

65. Roling, N.G.; Wagemakers, M.A.E. Facilitating Sustainable Agriculture: Participatory Learning and Adaptive Management in Times of Environmental Uncertainty; Cambridge University Press: Cambridge, UK, 2000.

66. Pellizzoni, L. Uncertainty and participatory democracy. Environ. Values 2003, 12, 195-224. [CrossRef]

67. Cornwall, A. Unpacking 'Participation': Models, meanings and practices. Community Dev. J. 2008, 43, $269-283$. [CrossRef]

68. Kolinjivadi, V.; Gamboa, G.; Adamowski, J.; Kosoy, N. Capabilities as justice: Analysing the acceptability of payments for ecosystem services (PES) through 'social multi-criteria evaluation'. Ecol. Econ. 2015, 118, $99-113$. [CrossRef]

69. Huang, J.; Tichit, M.; Poulot, M.; Darly, S.; Li, S.; Petit, C.; Aubry, C. Comparative review of multifunctionality and ecosystem services in sustainable agriculture. J. Environ. Manag. 2015, 149, 138-147. [CrossRef]

70. Steinhäußer, R.; Siebert, R.; Steinführer, A.; Hellmich, M. National and regional land-use conflicts in Germany from the perspective of stakeholders. Land Use Policy 2015, 49, 183-194. [CrossRef]

71. Swinton, S.M.; Lupi, F.; Robertson, G.P.; Hamilton, S.K. Ecosystem services and agriculture: Cultivating agricultural ecosystems for diverse benefits. Ecol. Econ. 2007, 64, 245-252. [CrossRef]

72. Power, A.G. Ecosystem services and agriculture: Tradeoffs and synergies. Philos. Trans. R. Soc. B Biol. Sci. 2010, 365, 2959-2971. [CrossRef]

73. Etxano Gandariasbeitia, I.; Barinaga-Rementeria Zabaleta, I.; García Alonso, O. Conflicting Values in Rural Planning: A Multifunctionality Approach through Social Multi-Criteria Evaluation. Sustainability 2018, 10, 1431. [CrossRef]

74. Kok, K.; Patel, M.; Rothman, D.S.; Quaranta, G. Multi-scale narratives from an IA perspective: Part II. Participatory local scenario development. Futures 2006, 38, 285-311. [CrossRef]

75. Garmendia, E.; Mariel, P.; Tamayo, I.; Aizpuru, I.; Zabaleta, A. Assessing the effect of alternative land uses in the provision of water resources: Evidence and policy implications from southern Europe. Land Use Policy 2012, 29, 761-770. [CrossRef]

76. Reed, M.S. Stakeholder participation for environmental management: A literature review. Biol. Conserv. 2008, 141, 2417-2431. [CrossRef]

77. Patel, M.; Kok, K.; Rothman, D.S. Participatory scenario construction in land use analysis: An insight into the experiences created by stakeholder involvement in the Northern Mediterranean. Land Use Policy 2007, 24, 546-561. [CrossRef]

78. Garmendia, E.; Gamboa, G.; Franco, J.; Garmendia, J.M.; Liria, P.; Olazabal, M. Social multi-criteria evaluation as a decision support tool for integrated coastal zone management. Ocean Coast. Manag. 2010, 53, 385-403. [CrossRef]

79. Morandeira Arca, J.; de Elizagarate Gutiérrez, V.; García Castro, D. Aproximación a las consecuencias de la orientación al mercado en el servicio público de fomento de la Economía Social vasca. CIRIEC-España Revista de Economía Pública, Social y Cooperativa 2017, 89, 80-105. [CrossRef]

80. Brandt, F.; Josefsson, J.; Spierenburg, M. Power and politics in stakeholder engagement: Farm dweller (in) visibility and conversions to game farming in South Africa. Ecol. Soc. 2018, 23, 32. [CrossRef] 
81. Voß, J.; Bornemann, B. The politics of reflexive governance: Challenges for designing adaptive management and transition management. Ecol. Soc. 2011, 16, 9. [CrossRef]

82. Cortina, J.M. What is coefficient alpha? An examination of theory and applications. J. Appl. Psychol. 1993, 78, 98. [CrossRef]

83. Bagozzi, R.P.; Yi, Y. On the evaluation of structural equation models. J. Acad. Mark. Sci. 1988, 16, 74-94. [CrossRef] article distributed under the terms and conditions of the Creative Commons Attribution (CC BY) license (http://creativecommons.org/licenses/by/4.0/). 